Original article

Section: Food Quality and Functionality

\title{
Macro- and Micro-Nutrient Composition and Antioxidant Activity of Chickpea and Pea Accessions
}

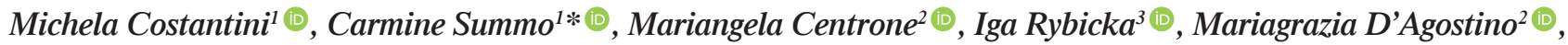

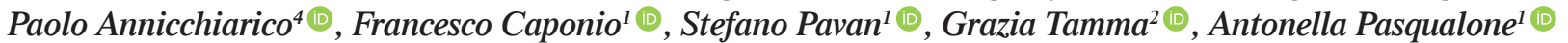

\author{
${ }^{1}$ Department of Soil, Plant and Food Science (DISSPA), University of Bari Aldo Moro, \\ via Amendola, 165/A, I-70126 Bari, Italy \\ ${ }^{2}$ Department of Bioscience, Biotechnologies and Biopharmaceutics (DBBB) University of Bari Aldo Moro, \\ via Amendola, 165/A, I-70126 Bari, Italy \\ ${ }^{3}$ Faculty of Commodity Science, Poznan University of Economics and Business, \\ al. Niepodlegtości 10, 61-875 Poznań, Poland \\ ${ }^{4}$ Research Centre for Animal Production and Aquaculture, Council for Agricultural Research and Economics (CREA), \\ viale Piacenza, 29, I-26900 Lodi, Italy
}

Key words: antioxidant activity, chickpeas, peas, phenolic extract, mineral composition, bioactive compounds

\begin{abstract}
Epidemiological studies reported an inverse association between the consumption of legumes and the incidence of age-related diseases. This trend could be attributed to the presence of antioxidant compounds, especially phenolic and flavonoid compounds. In this paper, five pea (Pisum sativum L.) and twelve chickpea (Cicer arietinum L.) accessions, having different characteristics and geographical origin, were characterised in terms of antioxidant activity, as well as macro- and micro-nutrient composition. The antioxidant activity has been evaluated using both DPPH (2,2-diphenyl-1-picrylhydrazyl) and ABTS (2,2'-azino-bis (3-ethylbenzthiazoline-6-sulfonic acid) radical scavenging capacity assays. Chickpea and pea accessions showed a dif-

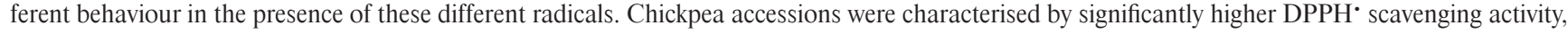
while peas showed a significantly higher value of antioxidant activity evaluated using the ABTS assay. Pea accessions had the highest content of total phenolic compounds, $\mathrm{Zn}$, and $\mathrm{Cu}$. A positive correlation was found between some minerals, such as $\mathrm{Zn}, \mathrm{Cu}$ and $\mathrm{P}$, and the ABTS ${ }^{\cdot+}$ scavenging activity. Black and brown chickpea accessions showed significantly higher contents of anthocyanins, $\mathrm{Mn}, \mathrm{Mg}$, and $\mathrm{Ca}$, which were positively correlated with the antioxidant activity assessed with the DPPH assay. Despite the dataset investigated in our study included a limited number of accessions, it was possible to highlight the influence of the chemical composition on the antioxidant activity due to the high phenotypic diversity found between the accessions, emphasising the importance of selecting the antioxidant activity assay according to the matrix to be evaluated.
\end{abstract}

\section{INTRODUCTION}

The demand for grain legume-based food is expected to increase in developing countries, as a consequence of the demographic growth, but also in the developed countries, given their contribution to a healthy diet and food safety. The increased awareness of risks associated with excessive consumption of animal proteins [Daryanto et al., 2015] and with fat accumulation due to the high intake of energy-dense foods poor in micronutrients and bioactive compounds also plays a determinant role in prompting legume consumption.

In addition, greater cultivation and consumption of food legumes has high priority to increase the sustainability of agriculture in terms of soil fertility, greenhouse gas emissions, energy efficiency, pollution, and crop diversity [Annicchiarico, 2017].
Chickpea (Cicer arietinum L.) is the third grain legume species cultivated worldwide [FAOSTAT data, 2018]. It has been shown that the two commercial types of chickpea, i.e. kabuli, with large seeds and beige coat, and desi, with small seeds and dark-coloured, fall in different genetic clusters [De Giovanni et al., 2017]. Furthermore, a black-pigmented chickpea type (Apulian black) traditionally cultivated in Apulia (Southern Italy), displayed peculiar phenotypic and genetic features [Pavan et al., 2017]. From a nutritional point of view, chickpeas are characterised by high dietary fibre and lipid content [Jukanti et al., 2012]. The lipid fraction, in particular for the coloured types such as desi and Apulian black type, has a high content of essential unsaturated fatty acids [Summo et al., 2019a,b] which elicit beneficial effects on human health [Jukanti et al., 2012].

Pea (Pisum sativum L.) is the fourth grain legume cultivated worldwide [FAOSTAT data, 2018], grown for both

\footnotetext{
* Corresponding Author: Fax: +39080 5443467;

e-mail: carmine.summo@uniba.it (Prof. C. Summo)
}

Submitted: 7 December 2020

Accepted: 15 April 2021

Published on-line: 19 May 2021 
human nutrition and livestock feeding. Studies on pea genetic diversity highlighted clear differentiation between the pea wild progenitor, $P$. sativum subsp. elatius, and the main pea cultivated subspecies (P. sativum subsp. sativum). Within P. sativum subsp. sativum, geographical patterns of variation were identified, as landraces from the Mediterranean area, the Caucasus, Ethiopia, and Central Asia exhibited peculiar genetic features [Smýkal et al., 2012].

As other legumes, pea (Pisum sativum L.) and chickpea (Cicer arietinum L.) are characterised by low levels of lipids and high contents of proteins, complex carbohydrates, B group vitamins, and minerals. They represent a good source of minerals, such as iron, zinc, calcium, magnesium, potassium, sulphur, and selenium [Ashokkumar et al., 2015] and carotenoids, such as $\beta$-carotene [Ashokkumar et al., 2015].

Both pea and chickpea have been studied for agronomic [Fotiadis et al., 2019], genetic [Pavan et al., 2017], and nutritional features [Summo et al., 2019a]. Furthermore, they have been proposed as functional ingredients of bakery products, such as bread and cakes [Millar et al., 2019; Pasqualone et al., 2019a], as well as ready-to-eat foods, such as purée and burgers [Summo et al., 2016, 2019c].

Moreover, epidemiological studies reported an inverse association between the consumption of legumes and the incidence of age-related diseases [Kris-Etherton et al., 2002]. The beneficial effect of legumes on health could be attributed to their content of phenolics and flavonoids [Fidrianny et al., 2016], which are the most active antioxidant compounds in foods [Dudonne et al., 2009]. Furthermore, antioxidant defences rely heavily on minerals in the diet, such as $\mathrm{Fe}, \mathrm{Mn}, \mathrm{Cu}, \mathrm{Zn}$, and Mg [Evans \& Halliwell, 2001]. Dietary antioxidant compounds can stimulate cellular defences and help prevent oxidative damage [Dudonne et al., 2009]. There are numerous published methods measuring the in $v i$ tro total antioxidant capacity. They can be classified in hydrogen atom transfer (HAT) or electron transfer (ET) based assays. The ET-based assays include the total phenols assay by Folin-Ciocalteu reagent, DPPH (2,2-diphenyl-1-picrylhydrazyl) and ABTS (2,2'-azino-bis (3-ethylbenzthiazoline-6-sulfonic acid) radical scavenging capacity assays [Huang et al., 2005]. Both $\mathrm{DPPH}^{\bullet}$ and $\mathrm{ABTS}^{*+}$ can be used to predict the antioxidant activity of vegetables, fruits, pulses, and food products [Fidrianny et al., 2016; Yao et al., 2013]. The principal aim of this study was to evaluate the antioxidant activity of chickpea and pea accessions by using two different radical scavenging capacity assays, such as DPPH and ABTS. Furthermore, proximate composition, contents of minerals, phenolic compounds, carotenoids, anthocyanins, and phytates of whole meal flour from the same accessions of chickpea and pea were determined. Finally, correlations between both antioxidant activities and legume flour composition were defined.

\section{MATERIAL AND METHODS}

\section{Plant material and flour preparation}

Twelve chickpea and five pea accessions were considered in this study, selected from the ex situ repositories of the United States Department of Agriculture (USDA),
TABLE 1. Chickpea (Cicer arietinum L.) and pea (Pisum sativum L.) accessions analysed.

\begin{tabular}{|c|c|c|c|c|c|}
\hline Legume & & Type & Seed size & Seed colour & Origin \\
\hline \multirow{12}{*}{$\begin{array}{l}\text { Chickpea } \\
\text { (Cicer } \\
\text { arietinum L.) }\end{array}$} & PI292006 & $\mathrm{KC}$ & Small & Beige & Jordan \\
\hline & PI339154* & $\mathrm{KC}$ & Large & Beige & Turkey \\
\hline & PI357648* & $\mathrm{KC}$ & Small & Beige & $\begin{array}{c}\text { Serbia- } \\
\text {-Montenegro }\end{array}$ \\
\hline & PI518255* & $\mathrm{DC}$ & Small & Brown & Afghanistan \\
\hline & PI251514* & $\mathrm{DC}$ & Small & Black & Iran \\
\hline & PI140293* & $\mathrm{DC}$ & Small & Brown & Iran \\
\hline & PI358934* & $\mathrm{DC}$ & Small & Black & Iran \\
\hline & PI533683* & $\mathrm{DC}$ & Large & Black & Spain \\
\hline & W610046* & $\mathrm{DC}$ & Large & Black & Bulgaria \\
\hline & $110694^{*}$ & $\mathrm{AB}$ & Large & Black & Italy \\
\hline & MG_13* & $\mathrm{AB}$ & Large & Black & Italy \\
\hline & MG_17* & $\mathrm{AB}$ & Large & Black & Italy \\
\hline \multirow{5}{*}{$\begin{array}{l}\text { Pea } \\
(\text { Pisum } \\
\text { sativum L.) }\end{array}$} & IG116297 & & Medium & Green & Turkey \\
\hline & ROR12 & & Large & Green & Italy \\
\hline & IG52442 & & Medium & $\begin{array}{c}\text { Green- } \\
\text {-pigmented }\end{array}$ & Syria \\
\hline & IG134828 & & Medium & $\begin{array}{c}\text { Green- } \\
\text {-pigmented }\end{array}$ & Georgia \\
\hline & IG51520 & & Medium & $\begin{array}{c}\text { Green- } \\
\text {-pigmented }\end{array}$ & Ethiopia \\
\hline
\end{tabular}

$\mathrm{KC}$ - kabuli chickpea, DC - desi chickpea, and AB - Apulian black chickpea.

*The chickpea accessions are part of a wide collection already characterised, whose data repository is in Summo et al. [2019a].

the Department of Plant, Soil and Food Science of the University of Bari, Italy (DiSSPA), and the Institute of Biosciences and Bioresources of the Italian National Research Council (CNR-IBBR) (Table 1). For each, type, country of origin, and phenotypic traits (seed size and colour) were indicated. Chickpea accessions encompassed the three genetic clusters previously identified, corresponding to the desi, kabuli, and Apulian black types [Pavan et al., 2017]. Genetic diversity of pea germplasm was ensured by selecting one accession referable to the wild progenitor P. sativum subsp. elatius collected in Syria, and four P. sativum subsp. sativum accessions originating from the Mediterranean area (Italy and Turkey), the Caucasus (Georgia), and Ethiopia. Among them, the Italian landrace ROR12 was reportedly resistant to the parasitic weed Orobanche crenata [Pavan et al., 2016]. All plants were grown in the experimental farm "P. Martucci" of the University of Bari "Aldo Moro", Italy (41 $01^{\prime} 22.1^{\prime}$ " $\mathrm{N}, 16^{\circ} 54^{\prime 21.0 "}$ E) during the growing season 2017-2018. They were harvested according to a randomised complete block design with two replicates, each replicate being formed by 30 individual plants. After harvesting at crop maturity, chickpea and pea seeds were milled (ETA mill, Vercella Giuseppe, Mercenasco, Italy) and sieved at $0.6 \mathrm{~mm}$. 


\section{Preparation of extracts and determination of the antioxidant activity}

Antioxidant activity was determined using both DPPH and $\mathrm{ABTS}$ radical (DPPH ${ }^{\bullet}$ and $\mathrm{ABTS}^{\bullet+}$ ) scavenging capacity assays. The determinations were performed for an aqueous-methanol extract $(20 / 80, v / v)$ prepared as reported by Summo et al. [2019b]. The DPPH radical scavenging capacity assay was carried out following the procedure described in Pasqualone et al. [2015]. The ABTS assay was performed according to Difonzo et al. [2017]. The antioxidant activity values were expressed as $\mu \mathrm{mol}$ of Trolox equivalent per $\mathrm{g}$ of dry matter (d.m.) of seeds. Each analysis was done in triplicate.

\section{Determination of nutritional composition and bioactive compounds in flours}

Proteins (total nitrogen $\times 5.7$ ), lipids, ashes, total dietary fibre, and moisture of the flours were determined according to the Association of Official Analytical Chemists (AOAC) methods 979.09, 945.38 F, 923.03, 991.43 and 925.10, respectively [AOAC, 2006]. Lipid content was determined. Carbohydrate content was calculated by difference.

Total carotenoid content was assessed using the method reported by Pasqualone et al. [2013] and was expressed as $\mathrm{mg}$ of $\beta$-carotene equivalent per $\mathrm{kg}$ of seed d.m.

Total anthocyanin content was determined as described by Pasqualone et al. [2015] and was expressed as mg of cyanidin 3-O-glucoside equivalent per $\mathrm{kg}$ of seed d.m.

Total phenolic compound (TPC) content was assessed as described by Summo et al. [2019b] using the extracts prepared as previously reported in section Preparation of extracts and determination of the antioxidant activity. The content of total phenolic compounds was expressed as mg of ferulic acid equivalent per g of seed d.m., considering a calibration curve prepared with ferulic acid at different concentrations.

Total phytate content was measured according to the method reported in Summo et al. [2019b].

\section{Determination of minerals in flours}

The determination of minerals in flours was performed by digesting using a microwave oven (CEM 6, Mars, CEM Corporation, Matthews, United States). Briefly, $0.5 \mathrm{~g}$ of each sample was weighed into a Teflon vessel, and $7 \mathrm{~mL}$ of $\mathrm{HNO}_{3}$ $(65 \%)$ and $1 \mathrm{~mL}$ of $\mathrm{H}_{2} \mathrm{O}_{2}(30 \%)$ were added [Rybicka \& Gliszczyńska-Świgło, 2017]. After cooling, digests were diluted to $50 \mathrm{~mL}$ with demineralised water (Hydrolab System, Wiślina, Poland) and kept at $4^{\circ} \mathrm{C}$ until spectroscopic determinations. Three digests were prepared for each sample. Spectroscopic determinations of minerals were performed using atomic emission spectroscopy and the method described in detail by Ozbek \& Akman [2016]. Analytical wavelengths for minerals were: $213.9 \mathrm{~nm}$ for $\mathrm{Zn}, 324.8 \mathrm{~nm}$ for $\mathrm{Cu}, 372.0 \mathrm{~nm}$ for Fe, $403.1 \mathrm{~nm}$ for $\mathrm{Mn}, 616.2 \mathrm{~nm}$ for $\mathrm{Ca}, 404.4 \mathrm{~nm}$ for $\mathrm{K}$, and $589.0 \mathrm{~nm}$ for $\mathrm{Na}$. The spectroscopic analysis was performed using two independent standard curves with a range from 0.05 to $1 \mu \mathrm{g} / \mathrm{mL}$ for microelements, 0.05 to $5 \mu \mathrm{g} / \mathrm{mL}$ for $\mathrm{Na}$, and from 10 to $100 \mu \mathrm{g} / \mathrm{mL}$ for other macroelements. Due to the high limit of quantification (LOQ) of phosphorus in atomic spectroscopy, its content was determined using the spectrophotometric molybdenum blue method adopted for multiple analysis using 48-microwell plates and microplate spectrophotometer (BioTek PowerWave XS2, Biokom, Warsaw, Poland) [Murphy $\&$ Riley, 1962]. Briefly, $0.16 \mathrm{~mL}$ of the sample, then $0.08 \mu \mathrm{L}$ of $5 \%$ ammonium molybdate, $0.08 \mu \mathrm{L}$ of $0.5 \%$ hydroquinone, and $0.08 \mu \mathrm{L}$ of $20 \%$ sodium sulphite were added to the well. The plate was shaken and left for $30 \mathrm{~min}$ in the dark; the absorbance was measured at $823 \mathrm{~nm}$.

\section{Statistical analysis}

Data were subjected to one-way ANOVA followed by Tukey's HSD test, considering both the differences between the species (chickpea vs. pea) and those among the accessions. Significant differences among the values of all recorded variables were determined at $p<0.05$ by the XLStat software (Addinsoft SARL, New York, NY, USA). Correlation analysis was performed by the same software.

\section{RESULTS AND DISCUSSION}

\section{Antioxidant activity evaluation}

The antioxidant activity has been evaluated using two different radical scavenging capacity assays, namely DPPH and ABTS, and expressed as $\mu \mathrm{mol}$ Trolox/g of dry matter (Figure 1). A different activity was observed between chickpea and pea accessions depending on the assay. Chickpea accessions were characterised by a significantly higher DPPH scavenging activity, while peas showed a significantly higher value of antioxidant activity when the ABTS assay was performed. The same trend has been reported by other researchers in green bean (Phaseolus radiates L.) and peanut (Arachis hypogaea L.) extracts [Fidrianny et al., 2016]. This result could be linked to the different chemical composition that characterised the two different legume species analysed. In fact, it has been shown that different phenolic compounds are responsible for quenching different free radicals [Xu et al., 2016]. In order to explain the different antioxidant activities between chickpea and pea species, correlations between in vitro radical scavenging capacity and compositional features of legume accessions were investigated.

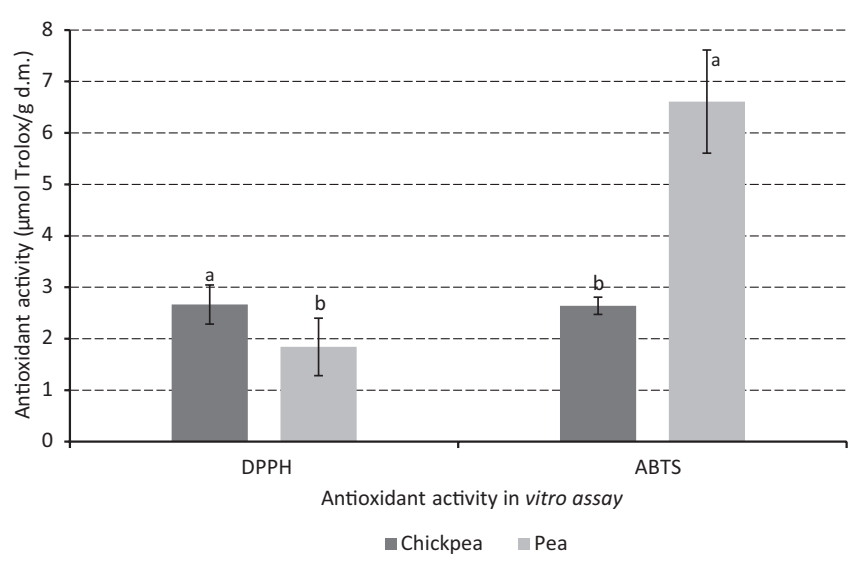

FIGURE 1. Mean values, standard deviation and results of the statistical analysis of antioxidant activity of chickpea and pea accessions assessed using both DPPH and ABTS radical scavenging assays. Different small letters indicate significant differences between the species $(p<0.05)$ for the type of antioxidant activity method used ( $n=12$ for chickpeas and $n=5$ for peas). 
TABLE 2. Proximate composition and content of bioactive compounds in the chickpea (Cicer arietinum L.) and pea (Pisum sativum L.) accessions analysed.

\begin{tabular}{|c|c|c|c|c|c|c|c|c|c|c|c|}
\hline & 离 & $\stackrel{\check{2}}{ٍ}$ & 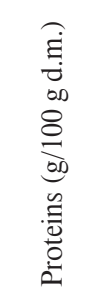 & 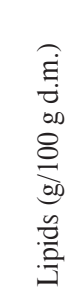 & 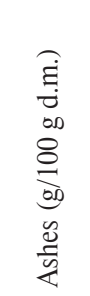 & 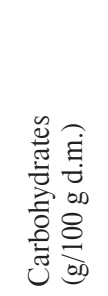 & 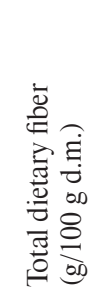 & 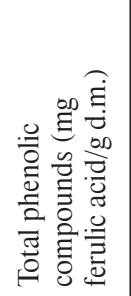 & 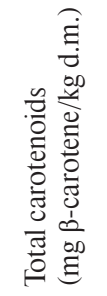 & 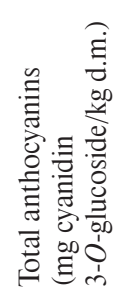 & 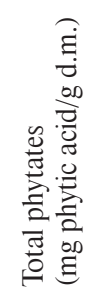 \\
\hline \multirow{12}{*}{ Chickpea* } & MG_13 & $\mathrm{AB}$ & 20.29 & 3.36 & 3.37 & 54.32 & 18.67 & 1.08 & 34.21 & 121.99 & 14.97 \\
\hline & MG_17 & $\mathrm{AB}$ & 17.31 & 4.42 & 2.69 & 59.86 & 15.72 & 0.82 & 41.26 & 79.16 & 9.66 \\
\hline & 110694 & $\mathrm{AB}$ & 22.71 & 3.35 & 3.90 & 52.84 & 17.20 & 0.96 & 42.76 & 119.00 & 11.36 \\
\hline & PI339154 & $\mathrm{KC}$ & 18.11 & 2.86 & 3.45 & 66.36 & 9.21 & 0.92 & 27.76 & 25.78 & 11.86 \\
\hline & PI292006 & $\mathrm{KC}$ & 20.34 & 4.16 & 3.64 & 60.60 & 11.26 & 0.69 & 29.46 & 32.45 & 14.72 \\
\hline & PI357648 & $\mathrm{KC}$ & 21.38 & 4.47 & 3.48 & 62.73 & 7.94 & 0.81 & 22.76 & 27.45 & 10.35 \\
\hline & PI518255 & DC & 17.80 & 2.83 & 3.75 & 45.81 & 29.82 & 0.71 & 46.85 & 44.37 & 15.29 \\
\hline & PI251514 & DC & 19.17 & 3.71 & 3.70 & 51.08 & 22.35 & 0.79 & 41.61 & 159.62 & 13.96 \\
\hline & PI140293 & $\mathrm{DC}$ & 19.32 & 2.80 & 3.47 & 49.39 & 25.03 & 1.08 & 26.01 & 46.52 & 11.79 \\
\hline & PI358934 & $\mathrm{DC}$ & 17.30 & 3.90 & 3.48 & 55.36 & 19.95 & 0.76 & 37.03 & 155.79 & 15.44 \\
\hline & PI533683 & DC & 20.19 & 3.35 & 3.70 & 52.70 & 20.06 & 1.04 & 42.27 & 115.40 & 11.02 \\
\hline & W610046 & $\mathrm{DC}$ & 25.92 & 3.41 & 3.65 & 48.87 & 18.15 & 0.83 & 48.92 & 103.23 & 11.95 \\
\hline Mean & & & $19.98^{\mathrm{B}}$ & $3.55^{\mathrm{A}}$ & $3.52^{\mathrm{A}}$ & $54.99^{\mathrm{A}}$ & $17.95^{\mathrm{A}}$ & $0,87^{\mathrm{B}}$ & $36.74^{\mathrm{A}}$ & $85.90^{\mathrm{A}}$ & $12.70^{\mathrm{A}}$ \\
\hline$D S$ & & & 2.50 & 0.59 & 0.30 & 6.20 & 6.37 & 0.14 & 8.59 & 49.63 & 2.06 \\
\hline \multirow{5}{*}{ Pea } & IG116297 & & 26.82 & 1.68 & 2.89 & 50.95 & 17.66 & 1.12 & 25.03 & 33.36 & 13.23 \\
\hline & ROR12 & & 24.42 & 1.52 & 3.32 & 58.07 & 12.67 & 1.22 & 16.72 & 19.26 & 10.71 \\
\hline & IG52442 & & 27.76 & 1.63 & 3.68 & 47.84 & 19.09 & 1.10 & 59.39 & 78.30 & 14.78 \\
\hline & IG134828 & & 26.75 & 2.06 & 3.45 & 53.69 & 14.04 & 1.05 & 33.59 & 72.63 & 13.99 \\
\hline & IG51520 & & 26.02 & 1.30 & 3.49 & 55.56 & 13.63 & 1.03 & 23.56 & 35.92 & 16.09 \\
\hline Mean & & & $26.36^{\mathrm{A}}$ & $1.64^{\mathrm{B}}$ & $3.36^{\mathrm{A}}$ & $53.22^{\mathrm{A}}$ & $15.42^{\mathrm{A}}$ & $1.10^{\mathrm{A}}$ & $31.66^{\mathrm{A}}$ & $47.89^{\mathrm{A}}$ & $13.76^{\mathrm{A}}$ \\
\hline$D S$ & & & 1.25 & 0.28 & 0.30 & 3.98 & 2.79 & 0.07 & 16.62 & 26.03 & 2.01 \\
\hline
\end{tabular}

KC - kabuli chickpea, DC - desi chickpea, and AB - Apulian black chickpea.

Different letters indicate significant differences between the species at $p<0.05$. *The chickpea accessions are part of a wide collection already characterised, whose data repository is in Summo et al. [2019a].

Nutritional composition and bioactive compound content

Table 2 reports proximate composition and content of bioactive compounds of chickpea and pea accessions examined in this study. Significant differences $(p<0.05)$ between the two species were found for protein, lipid, and carbohydrate contents. Chickpea showed a significantly higher lipid content and significantly lower protein and carbohydrate contents than pea. No significant differences $(p>0.05)$ between species emerged for total dietary fibre content, possibly due to the high variability observed among the accessions within the species.

Data on the chemical composition and bioactive compound content of a collection of chickpea accessions, including the twelve ones tested in this study, were reported and discussed in our previous work [Summo et al., 2019b]. Considering the data on the pea accessions (Table 2), a large variation was currently observed among the pea accessions, especially for bioactive compounds. In particular, the accession ROR12 showed the highest value of total phenolic compounds (1.22 mg ferulic acid/g d.m.). The observed mean value of total phenolic compounds was higher than the levels obtained by Zia-Ul-Haq et al. [2013], who reported $0.99 \mathrm{mg} / \mathrm{g}$ as a maximum value of total phenolic compounds detected in the cultivar Climax. Notably, at a high concentration, antioxidants can act as pro-oxidants by reacting with molecular oxygen [Sotler et al., 2019]. Due to the high metabolic rate, reactive oxygen species (ROS) generation is incredibly high in transformed cells [Perillo et al., 2020].

The total carotenoid content also varied considerably among pea accessions, ranging from $16.72 \mathrm{mg} \beta$-carotene $/ \mathrm{kg}$ d.m. in the accession ROR12 to $59.39 \mathrm{mg} \beta$-carotene $/ \mathrm{kg}$ d.m. in the IG52442. Ashokkumar et al. [2015], examining a collection of 94 pea genotypes, found a carotenoid content in pea ranging from 10 to $27 \mu \mathrm{g} / \mathrm{g}$ in accessions with green cotyledons, and from 5 to $17 \mu \mathrm{g} / \mathrm{g}$ in accessions with yellow cotyledons. 
TABLE 3. Mineral composition of the chickpea (Cicer arietinum L.) and pea (Pisum sativum L.) accessions analysed.

\begin{tabular}{|c|c|c|c|c|c|c|c|c|c|c|c|}
\hline & 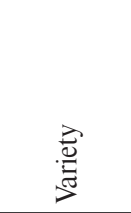 & $\stackrel{ٍ}{ٍ}$ & 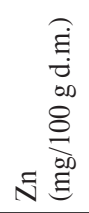 & 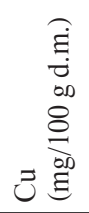 & 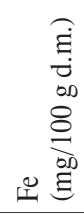 & 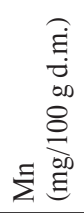 & 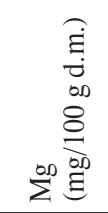 & 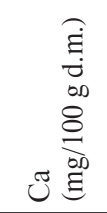 & 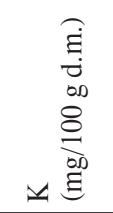 & 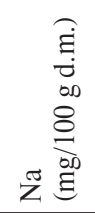 & 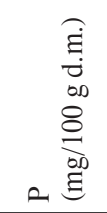 \\
\hline \multirow{12}{*}{ Chickpea } & MG_13 & $\mathrm{AB}$ & 4.46 & 1.03 & 4.22 & 2.48 & 176.49 & 194.69 & 898.45 & 4.89 & 405.82 \\
\hline & MG_17 & $\mathrm{AB}$ & 2.81 & 0.29 & 3.78 & 4.78 & 153.95 & 290.81 & 756.18 & 2.89 & 297.10 \\
\hline & 110694 & $\mathrm{AB}$ & 2.65 & 0.37 & 4.26 & 3.63 & 184.57 & 219.68 & 1055.07 & 7.00 & 425.91 \\
\hline & PI339154 & $\mathrm{KC}$ & 2.80 & 0.43 & 2.95 & 3.40 & 173.57 & 146.50 & 1159.11 & 7.53 & 456.10 \\
\hline & PI292006 & $\mathrm{KC}$ & 2.80 & 0.31 & 3.52 & 3.07 & 168.78 & 211.94 & 1009.69 & 9.09 & 406.16 \\
\hline & PI357648 & $\mathrm{KC}$ & 2.49 & 0.23 & 2.73 & 3.26 & 160.20 & 174.71 & 957.08 & 9.99 & 386.94 \\
\hline & PI518255 & DC & 3.05 & 0.36 & 4.22 & 4.32 & 179.79 & 431.83 & 1034.08 & 15.48 & 419.95 \\
\hline & PI251514 & DC & 2.15 & 0.25 & 4.11 & 3.66 & 183.79 & 334.91 & 1027.31 & 39.36 & 394.75 \\
\hline & PI140293 & DC & 2.38 & 0.20 & 3.20 & 3.84 & 188.73 & 279.21 & 984.70 & 19.91 & 386.19 \\
\hline & PI358934 & DC & 2.25 & 0.22 & 3.44 & 4.34 & 190.05 & 376.76 & 1005.02 & 16.69 & 364.63 \\
\hline & PI533683 & DC & 2.35 & 0.23 & 3.68 & 4.03 & 179.16 & 305.03 & 980.09 & 1.83 & 395.08 \\
\hline & W610046 & DC & 1.99 & 0.21 & 3.25 & 3.32 & 175.69 & 210.17 & 1007.91 & 2.11 & 395.15 \\
\hline Mean & & & $2.68^{\mathrm{B}}$ & $0.34^{\mathrm{B}}$ & $3.61^{\mathrm{B}}$ & $3.68^{\mathrm{A}}$ & $176.22^{\mathrm{A}}$ & $264.69^{\mathrm{A}}$ & $989.56^{\mathrm{A}}$ & $11.40^{\mathrm{A}}$ & $394.48^{\mathrm{A}}$ \\
\hline$D S$ & & & 0.64 & 0.23 & 0.52 & 0.63 & 10.92 & 86.70 & 95.99 & 10.59 & 38.37 \\
\hline \multirow{5}{*}{ Pea } & IG116297 & & 3.74 & 0.87 & 4.00 & 0.96 & 157.63 & 117.07 & 884.55 & 3.14 & 474.17 \\
\hline & ROR12 & & 3.16 & 0.56 & 3.69 & 1.12 & 153.90 & 90.96 & 937.62 & 5.02 & 412.93 \\
\hline & IG52442 & & 4.39 & 0.84 & 5.23 & 1.07 & 177.15 & 119.61 & 996.19 & 2.97 & 543.83 \\
\hline & IG134828 & & 4.08 & 0.72 & 4.66 & 0.99 & 163.56 & 97.07 & 979.05 & 3.15 & 503.97 \\
\hline & IG51520 & & 2.56 & 0.70 & 3.87 & 1.02 & 166.99 & 129.17 & 971.88 & 1.64 & 421.20 \\
\hline Mean & & & $3.58^{\mathrm{A}}$ & $0.74^{\mathrm{A}}$ & $4.29^{\mathrm{A}}$ & $1.03^{\mathrm{B}}$ & $163.85^{\mathrm{B}}$ & $110.78^{\mathrm{B}}$ & $953.86^{\mathrm{A}}$ & $3.18^{\mathrm{A}}$ & $471.22^{\mathrm{A}}$ \\
\hline$D S$ & & & 0.73 & 0.12 & 0.64 & 0.06 & 9.01 & 16.10 & 44.21 & 1.21 & 55.35 \\
\hline
\end{tabular}

KC - kabuli chickpea, DC - desi chickpea, and AB - Apulian black chickpea. Different letters indicate significant differences between the species at $p<0.05$.

The total anthocyanin content varied from $19.26 \mathrm{mg}$ cyanidin 3-O-glucoside $/ \mathrm{kg} \mathrm{d} . \mathrm{m}$. in the non-pigmented pea accession ROR12 to $78.30 \mathrm{mg}$ cyanidin $3-\mathrm{O}$-glucoside $/ \mathrm{kg}$ d.m in the pigmented accession pea IG52442. Notably, anthocyanin content was highly variable even within pigmented accessions with the minimum value $(23.56 \mathrm{mg}$ cyanidin 3-O-glucoside/kg d.m) displayed by the accession IG 51520 .

Legumes contain non-nutritional factors, such as phytates, that can reduce the bioavailability of some compounds or inhibit the enzymes necessary for their digestion [Shi et al., 2018]. As reported in Table 2, no significant differences were observed between the two species, although considerable variation was found among the individual accessions. Pea accessions under the study showed a higher content of phytic acid than green and yellow peas studied by other researchers. Millar et al. [2019] reported that phytic acid content was $543.41 \mathrm{mg} / 100 \mathrm{~g}$ in the green pea and $574.14 \mathrm{mg} / 100 \mathrm{~g}$ in the yellow one was $574.14 \mathrm{mg} / 100 \mathrm{~g}$ [Millar et al., 2019].
Phytic acid is the principal storage form of phosphorus in seeds; this compound and its salts are capable of forming complexes with minerals, such as $\mathrm{Ca}, \mathrm{Cu}, \mathrm{Mg}, \mathrm{Fe}$, and $\mathrm{Zn}$, thereby having a negative effect on their gastrointestinal absorption [Shi et al., 2018].

\section{Mineral composition}

Potassium (K) was the most abundant mineral found in both chickpeas and peas (Table 3), without significant differences between them. Instead, significant differences were observed for other minerals such as zinc ( $\mathrm{Zn})$, copper $(\mathrm{Cu})$, iron $(\mathrm{Fe})$, manganese $(\mathrm{Mn})$, magnesium $(\mathrm{Mg})$, calcium $(\mathrm{Ca})$, and phosphorus $(\mathrm{P})(p<0.05)$. Chickpeas had the highest contents of $\mathrm{Mn}, \mathrm{Mg}$, and $\mathrm{Ca}$. Magnesium and calcium contents in chickpeas were higher than those (mean values of 1402 and $1040 \mu \mathrm{g} / \mathrm{g}$, respectively) reported in Vandemark et al. [2018], but similar to those reported by Kaya et al. [2018]. Peas had significantly higher $\mathrm{Zn}, \mathrm{Cu}, \mathrm{Fe}$, and $\mathrm{P}$ values 
TABLE 4. Correlation table (correlation coefficient $-r$ values) between the in vitro antioxidant activity (DPPH and ABTS assays) and chemical compound contents determined in the pulse accessions.

\begin{tabular}{c|c|c|c|c|c|c|c|c|c|c|c|c|c|c|c|c|c|c}
\hline & Pr & L & A & C & DF & TPC & TC & TA & PH & Zn & Cu & Fe & Mn & $\mathrm{Mg}$ & $\mathrm{Ca}$ & $\mathrm{K}$ & $\mathrm{Na}$ & $\mathrm{P}$ \\
\hline DPPH & -0.53 & $\mathbf{0 . 5 8}$ & -0.04 & -0.14 & 0.34 & -0.31 & $\mathbf{0 . 6 6}$ & $\mathbf{0 . 6 4}$ & 0.13 & -0.11 & -0.13 & 0.14 & $\mathbf{0 . 6 4}$ & 0.45 & 0.53 & -0.20 & 0.04 & -0.48 \\
ABTS & $\mathbf{0 . 7 3}$ & $\mathbf{- 0 . 7 9}$ & -0.46 & -0.02 & -0.26 & $\mathbf{0 . 5 9}$ & -0.50 & -0.43 & 0.01 & $\mathbf{0 . 5 9}$ & $\mathbf{0 . 6 1}$ & 0.39 & $\mathbf{- 0 . 8 6}$ & $\mathbf{- 0 . 5 9}$ & $\mathbf{- 0 . 6 8}$ & -0.26 & -0.31 & $\mathbf{0 . 7 0}$
\end{tabular}

Pr - Proteins; L - Lipids; A - Ashes; C - Carbohydrates; DF - Dietary fibers; TPC - Total phenolic compounds; TC - Total carotenoids; TA - Total anthocyanins; $\mathrm{PH}$ - Phytates; $r$ values in bold indicate a significant correlation $(p<0.05)$.

than chickpeas. The values found in our study agree with Wang \& Daun [2004], who reported a range of 2.50-5.20, $0.40-0.90,4.30-7.90$, and 270.30-950.50 mg/100 g for $\mathrm{Zn}$, $\mathrm{Cu}, \mathrm{Fe}$, and $\mathrm{P}$, respectively.

At the intraspecific level, Apulian black and some desi chickpea accessions showed a high Fe content, with the highest value observed in the accession 110694 (4.26 mg/100 g d.m.). In contrast, kabuli chickpeas were characterised by a low $\mathrm{Fe}$ content, with the lowest value found in the accession PI357648 ( $2.73 \mathrm{mg} / 100 \mathrm{~g} \mathrm{d.m.).} \mathrm{In} \mathrm{accordance} \mathrm{with} \mathrm{the} \mathrm{previous} \mathrm{study}$ of Jukanti et al. [2012], DC accessions showed the highest Ca content (mean value $322.99 \mathrm{mg} / 100 \mathrm{~g} \mathrm{d.m}$.), followed by AC (mean value $235.36 \mathrm{mg} / 100 \mathrm{~g} \mathrm{~d}$.m.) and kabuli (mean value $177.72 \mathrm{mg} / 100 \mathrm{~g}$ d.m.). The DC accession PI518255 displayed the highest Ca content (431.83 mg/100 g d.m.), which was found to be far from the mean value shown for chickpeas $(264.69 \mathrm{mg} / 100 \mathrm{~g} \mathrm{~d} . \mathrm{m}$.). The AB variety MG_13 had the highest $\mathrm{Zn}$ and $\mathrm{Cu}$ levels (4.26 and $1.03 \mathrm{mg} / 100 \mathrm{~g}$ d.m., respectively).

Peas were characterised by a low variability among different accessions. However, the pigmented variety IG51520 had the highest content of Ca (129.17 mg/100 g d.m.), which was higher than the maximum value $(106.90 \mathrm{mg} / 100 \mathrm{~g})$ reported by Wang \& Daun [2004].

\section{Correlations between antioxidant activity and flour composition}

Correlations between in vitro radical scavenging capacity and compositional features of legume accessions are reported in the Table 4.

A positive correlation was observed between the total phenolic content and ABTS $^{*+}$ scavenging activity $(r=0.59$; $p<0.05)$. On the contrary, a negative, but not significant $(p>0.05)$ correlation was observed between ABTS assay results and contents of both carotenoids and anthocyanins. Considering the same compounds, an inverse trend was found for DPPH ${ }^{\bullet}$ scavenging activity. Bioactive compounds, such as phenolics, carotenoids, and anthocyanins, are recognised as antioxidants. Thus, they can prevent or reduce lipid peroxidation and scavenge free oxygen radicals through their high antioxidant activities [Ashokkumar et al., 2015]. Moreover, phenolic compounds exhibit anti-tumoral, anti-inflammatory, and anti-allergic properties while anthocyanins are important due to their anti-carcinogenic properties and the ability to limit the incidence of hepatic steatosis and cardiovascular diseases, to control obesity, and to mitigate diabetes [Hernandez-Velazquez et al., 2020]. Interestingly a significant association has been found between the total flavonoid intake and a high level of magnesium, paralleled by a reduction of the metabolic syndrome [Jin et al., 2020].

By contrast, several flavonoids, known for their antioxidant features, were proved, instead, to act as prooxidants and mutagenic factors in the in vitro studies [Rahal et al., 2014]. A study conducted to determine the potential of grape pomace extracts as a source of natural antioxidants reported a positive correlation between $\mathrm{ABTS}^{\cdot+}$ scavenging capacity and total phenolic contents, as well as with the total flavonoid contents [Xu et al., 2016]. Yao et al. [2013] confirmed these results in black mung beans, where a significant positive correlation was found between bound phenolic acids and $\mathrm{ABTS}^{\cdot+}$ scavenging activity $(r=0.941 ; p<0.01)$. Flavonoids and tannins have a relevant influence on the ABTS antioxidant activity, while anthocyanin compounds give a greater contribution to the antioxidant capacity measured by DPPH test, as shown by Xu et al. [2016] in pomace extracts. Furthermore, a negative correlation between $\mathrm{ABTS}^{*}$ scavenging activity and $\beta$-carotene was reported by Thaipong et al. [2006] for methanol extracts from guava fruit. Considering the nutritional composition, the ABTS data showed a positive correlation with protein content $(r=0.73 ; p<0.01)$, whereas the same data were negatively correlated with lipid content $(r=-0.79$; $p<0.01$ ) (Table 4). As previously reported by other researchers in leguminous seeds [Grela et al., 2017], a positive correlation was found between DPPH${ }^{\bullet}$ scavenging activity and lipid contents $(r=0.58 ; p<0.05)$. Grela et al. [2017] have reported a high correlation between $\mathrm{DPPH}^{\bullet}$ scavenging activity and unsaturated fatty acid contents, especially polyunsaturated ones, in several legumes, namely lupines, peas, chickpeas, lentils, grass peas, and common beans. In contrast, no correlation between fatty acids and $\mathrm{DPPH}^{*}$ scavenging activity in 20 Canadian lentils cultivars was reported by Zhang et al. [2014]. Usually, the number of unsaturated bonds in the fatty acids induces an exponential increase in the susceptibility to oxidation. Therefore, the content of the individual double bonds of fatty acids may not be directly related in a linear way to the antioxidant activity. The positive correlation between the antioxidant activity (measured by DPPH test) and lipid content found in our study may suggest that other compounds have a significant influence on the resistance to oxidation of fatty acids [Grela et al., 2017]. For instance, as mentioned above, carotenoids, anthocyanins, and phenolic compounds can contribute to the increase in the antioxidant potential.

A significant negative correlation was found between $\mathrm{ABTS}^{\bullet+}$ scavenging activity and $\mathrm{Mn}(r=-0.86 ; p<0.01)$, $\mathrm{Mg}(r=-0.59 ; p<0.05)$ and $\mathrm{Ca}(r=-0.68 ; p<0.01)$, whereas 
the correlation was positive for $\mathrm{Zn}(r=0.59 ; p<0.05), \mathrm{Cu}$ $(r=0.61 ; p<0.05)$ and $\mathrm{P}(r=0.70 ; p<0.01)$. No significant correlation between $\mathrm{DPPH}^{\bullet}$ scavenging activity and mineral compounds was found, except for Mn $(r=0.64 ; p<0.05)$. Despite the large amount of information available in scientific literature on mineral content of legumes, to the best of our knowledge, there are no reports on the direct correlation between mineral content and antioxidant activity. However, several studies suggested that an imbalance of minerals would change the content of polyphenols and flavonoids [Grela et al., 2017; Sulaiman et al., 2011]. This behaviour may explain the positive correlation found for the content of $\mathrm{Mn}$ and $\mathrm{DPPH}^{*}$ scavenging activity. In fact, $\mathrm{Mn}$ is involved in activating enzymes that enhance the biosynthesis of flavonoids [Gordon, 2007]. A significant correlation between Mn content and $\mathrm{DPPH}^{\bullet}$ scavenging activity was reported by Sulaiman et al. [2011] in banana (Musa sp.) fresh pulps and peels. Furthermore, Zn-deficient or Zn-excess conditions cause changes in the antioxidant enzyme activities, as shown in bean plants by Prabhu Inbaraj \& Muthuchelian [2011]. Tewari et al. [2006] reported, instead, an increase in the activity of the antioxidative enzyme superoxide dismutase (SOD) in mulberry (Morus rubra L.) Mg-deficient plants, suggesting an inverse relationship between $\mathrm{Mg}$ and antioxidant activity. Other researchers reported a significant correlation between the total flavonoid content and minerals due to the chelating role of polyphenols, especially condensed tannins [Rehecho et al., 2011]. Therefore, these compounds may prevent or delay metal-catalised initiation and decomposition of lipid hydroperoxides. Rehecho et al. [2011] reported significant correlations between the total flavonoid content and minerals, such as $\mathrm{K}, \mathrm{Zn}, \mathrm{Cu}, \mathrm{Ca}$, and $\mathrm{Mg}$ in verbena extracts.

\section{CONCLUSION}

Chickpea and pea accessions showed a different antiradical activity against $\mathrm{DPPH}^{\bullet}$ and $\mathrm{ABTS}^{\cdot+}$. In particular, chickpea accessions were characterised by significantly higher DPPH ${ }^{*}$ scavenging activity, while pea showed a significantly a higher value of antioxidant activity evaluated using the ABTS assay.

Pea accessions had the highest content of total phenolic compounds, $\mathrm{Zn}$ and $\mathrm{Cu}$. A positive correlation was found between some minerals, such as $\mathrm{Zn}, \mathrm{Cu}$ and $\mathrm{P}$, and the ABTS •+ scavenging activity found. Black and brown chickpea accessions showed a significantly higher content of anthocyanins, $\mathrm{Mn}, \mathrm{Mg}$ and $\mathrm{Ca}$, which were positively correlated with the antioxidant activity assessed by the DPPH assay. Therefore, the high phenolic content found in pea accessions was linked to the higher $\mathrm{ABTS}^{\bullet+}$ scavenging capacity, while chickpeas, especially Apulian black and desi types, having high carotenoid and anthocyanin contents, were able to quench the DPPH radical.

Furthermore, the content of minerals and their composition may influence the antioxidant activity, especially $\mathrm{ABTS}^{\cdot+}$ scavenging. Indeed, a significant negative correlation was found between ABTS ${ }^{*+}$ scavenging activity and $\mathrm{Mn}$, $\mathrm{Mg}$, and $\mathrm{Ca}$, whereas the correlation was positive for $\mathrm{Zn}, \mathrm{Cu}$, and $\mathrm{P}$.
Despite the dataset investigated in our study included a limited number of accessions, it was possible to highlight the influence of the chemical composition on the antioxidant activity due to the high phenotypic diversity found between the accessions, emphasising the importance of selecting the antioxidant activity assay according to the matrix to be evaluated.

\section{RESEARCH FUNDING}

This research has been performed within the project "LEgume GEnetic REsources as a tool for the development of innovative and sustainable food TEchnological system" supported under the "Thought for Food" Initiative by Agropolis Fondation (through the "Investissements d'avenir" programme with reference number ANR-10-LABX-0001-01), Fondazione Cariplo, and Daniel \& Nina Carasso Foundation.

\section{CONFLICT OF INTEREST}

Authors declare no conflict of interest.

\section{ORCID IDs}

P. Annicchiarico https://orcid.org/0000-0001-8027-1035

F. Caponio https://orcid.org/0000-0002-0740-7677

M. Centrone https://orcid.org/0000-0001-5469-3365

M. Costantini https://orcid.org/0000-0002-8273-1039

M. D’Agostino https://orcid.org/0000-0001-6127-9656

A. Pasqualone https://orcid.org/0000-0001-6675-2203

S. Pavan https://orcid.org/0000-0002-3666-7291

I. Rybicka https://orcid.org/0000-0003-1679-328X

C. Summo https://orcid.org/0000-0002-2736-7705

G. Tamma https://orcid.org/0000-0002-8890-0278

\section{REFERENCES}

1. Annicchiarico, P. (2017). Feed legumes for truly sustainable crop-animal systems. Italian Journal of Agronomy, 12, 151-160. https://doi.org/10.4081/ija.2017.880

2. AOAC International (2006). Official Methods of Analysis (17th ed.). Association of Official Analytical Chemists, Gaithersburg, MD.

3. Ashokkumar, K., Diapari, M., Jha, A.B., Tar'an, B., Arganosa, G., Warkentin, T.D. (2015). Genetic diversity of nutritionally important carotenoids in 94 pea and 121 chickpea accessions. Journal of Food Composition and Analysis, 43, 49-60. https://doi.org/10.1016/j.jfca.2015.04.014

4. Daryanto, S., Wang, L., Jacinthe, P.A., (2015). Global synthesis of drought effects on food legume production. Plos One, 10(6), art. no. e0127401.

https://doi.org/10.1371/journal.pone.0127401

5. De Giovanni, C., Pavan, S., Taranto, F., Di Rienzo, V., Miazzi, M.M., Marcotrigiano, R., Mangini, G., Montemurro, C., Ricciardi, L., Lotti, C. (2017). Genetic variation of a global germplasm collection of chickpea (Cicer arietinum L.) including Italian accessions at risk of genetic erosion. Physiology and Molecular Biology of Plants, 23, 197-205.

https://doi.org/10.1007/s12298-016-0397-4 
6. Difonzo, G., Russo, A., Trani, A., Paradiso, V.M., Ranieri, M., Pasqualone, A., Summo, C., Tamma, G., Silletti, R., Caponio, F. (2017). Green extracts from Coratina olive cultivar leaves: Antioxidant characterization and biological activity. Journal of Functional Foods, 31, 63-70.

https://doi.org/10.1016/j.jff.2017.01.039

7. Dudonne, S., Vitrac, X., Coutiere, P., Woillez, M., Mérillon, J.M. (2009). Comparative study of antioxidant properties and total phenolic content of 30 plant extracts of industrial interest using DPPH, ABTS, FRAP, SOD, and ORAC assays. Journal of Agricultural and Food Chemistry, 57(5), 1768-1774.

https://doi.org/10.1021/jf803011r

8. Evans, P., Halliwell, B. (2001). Micronutrients: oxidant/antioxidant status. British Journal of Nutrition, 85(S2), S67-S74. https://doi.org/10.1079/BJN2000296

9. Food and Agriculture Organization of the United Nations (2018). Data of Crops Production. (Accessed 02 November 2020).

10. Fotiadis, S., Koutroubas, S.D., Damalas, C.A. (2019). Nitrogen utilization and yield determination of spring mediterranean chickpea as influenced by planting date and environmental conditions. International Journal of Plant Production, 13(1), 59-72. https://doi.org/10.1007/s42106-018-0034-y

11. Fidrianny, I., Elviana, D., Ruslan, K. (2016). In vitro antioxidant activities in various beans extracts of five legumes from West of Java-Indonesia using DPPH and ABTS methods. International Journal of Pharmacognosy and Phytochemical Research, 8(3), 470-476.

12. Gordon, B. (2007). Manganese nutrition of glyphosate-resistant and conventional soybeans. Better Crops, 91 (4), 12-13.

13. Grela, E.R., Samolińska, W., Kiczorowska, B., Klebaniuk, R., Kiczorowski, P. (2017). Content of minerals and fatty acids and their correlation with phytochemical compounds and antioxidant activity of leguminous seeds. Biological Trace Element Research, 180(2), 338-348.

https://doi.org/10.1007/s12011-017-1005-3

14. Hernandez-Velazquez, I., Sanchez-Tapia, M., Ordaz-Nava, G., Torres, N., Tovar, A.R., Galvez, A. (2020). Black bean protein concentrate ameliorates hepatic steatosis by decreasing lipogenesis and increasing fatty acid oxidation in rats fed a high fat-sucrose diet. Food and Function, 11 (12), 10341-10350. https://doi.org/10.1039/DOFO02258F

15. Huang, D., Ou, B., Prior, R.L. (2005). The chemistry behind antioxidant capacity assays. Journal of Agricultural and Food Chemistry, 53(6), 1841-1856. https://doi.org/10.1021/jf030723c

16. Jin, S., Liu, J., Jia, Y., Han, T., Zhao, X., Sun, C., Na, L. (2020). The association of dietary flavonoids, magnesium and their interactions with the metabolic syndrome in Chinese adults: a prospective cohort study. British Journal of Nutrition, 1-11. https://doi.org/10.1017/S0007114520004754

17. Jukanti, A.K., Gaur, P.M., Gowda, C., Chibbar, R.N. (2012). Nutritional quality and health benefits of chickpea (Cicer arietinum L.): a review. British Journal of Nutrition, 108(S1), S11-S26. https://doi.org/10.1017/S0007114512000797

18. Kaya, M., Kan, A., Yilmaz, A., Karaman, R., Sener, A. (2018). The fatty acid and mineral compositions of different chickpea cultivars cultivated. Fresenius Environmental Bulletin, 27(2), 1240-1247.

19. Kris-Etherton, P.M., Hecker, K.D., Bonanome, A., Coval, S.M., Binkoski, A.E., Hilpert, K.F., Griel, A.E., Etherton, T.D. (2002). Bioactive compounds in foods: their role in the prevention of cardiovascular disease and cancer. The American Journal of Medicine, 113(9), 71-88.

https://doi.org/10.1016/S0002-9343(01)00995-0

20. Millar, K.A., Barry-Ryan, C., Burke, R., McCarthy, S., Gallagher, E. (2019). Dough properties and baking characteristics of white bread, as affected by addition of raw, germinated and toasted pea flour. Innovative Food Science and Emerging Technologies, 56, art. no. 102189 .

https://doi.org/10.1016/j.ifset.2019.102189

21. Murphy, J., Riley, J.P. (1962). A modified single solution method for the determination of phosphate in natural waters. Analytica Chimica Acta, 27, 31-36.

https://doi.org/10.1016/S0003-2670(00)88444-5

22. Ozbek, N., Akman, S. (2016). Method development for the determination of calcium, copper, magnesium, manganese, iron, potassium, phosphorus and zinc in different types of breads by microwave induced plasma-atomic emission spectrometry. Food Chemistry, 200, 245-248.

https://doi.org/10.1016/j.foodchem.2016.01.043

23. Pasqualone, A., Bianco, A.M., Paradiso, V.M. (2013). Production trials to improve the nutritional quality of biscuits and to enrich them with natural anthocyanins. CyTA - Journal of Food, 11, 301-308.

https://doi.org/10.1080/19476337.2012.753113

24. Pasqualone, A., Bianco, A.M., Paradiso, V.M., Summo, C., Gambacorta, G., Caponio, F., Blanco, A. (2015). Production and characterization of functional biscuits obtained from purple wheat. Food Chemistry, 180, 64-70.

https://doi.org/10.1016/j.foodchem.2015.02.025

25. Pasqualone, A., De Angelis, D., Squeo, G., Difonzo, G., Caponio, F., Summo, C., (2019a). The effect of the addition of Apulian black chickpea flour on the nutritional and qualitative properties of durum wheat-based bakery products. Foods, $8(10)$, art. no. 504.

https://doi.org/10.3390/foods8100504

26. Pavan, S., Lotti, C., Marcotrigiano, A.R., Mazzeo, R., Bardaro, N., Bracuto, V., De Giovanni, C. (2017). A distinct genetic cluster in cultivated chickpea as revealed by genome-wide marker discovery and genotyping. The Plant Genome, 10(2), 1-9. https://doi.org/10.3835/plantgenome2016.11.0115

27. Pavan, S., Schiavulli, A., Marcotrigiano, A.R., Bardaro, N., Bracuto, V., Ricciardi, F., Charnikhova, T., Lotti, C., Bouwmeester, H., Ricciardi, L. (2016). Characterization of low-strigolactone germplasm in pea (Pisum sativum L.) resistant to crenate broomrape (Orobanche crenata Forsk.). Molecular Plant-Microbe Interactions, 29(10), 743-749.

https://doi.org/10.1094/MPMI-07-16-0134-R

28. Perillo, B., Di Donato, M., Pezone, A., Di Zazzo, E., Giovannelli, P., Galasso, G., Castoria, G., Migliaccio, A. (2020). ROS in cancer therapy: the bright side of the moon. Experimental and Molecular Medicine, 52(2), 192-203.

https://doi.org/10.1038/s12276-020-0384-2

29. Prabhu Inbaraj, M., Muthuchelian, K. (2011). The effect of zinc stress combined with high irradiance stress on membrane damage and antioxidative response in bean seedlings. Environmental and Experimental Botany, 74, 171-177.

https://doi.org/10.1016/j.envexpbot.2011.05.016

30. Rahal, A., Kumar, A., Singh, V., Yadav, B., Tiwari, R., Chakraborty, S., Dhama, K. (2014). Oxidative stress, prooxidants, and antioxi- 
dants: the interplay. BioMed Research International, 2014, art. no. 761264

\section{https://doi.org/10.1155/2014/761264}

31. Rehecho, S., Hidalgo, O., De Cirano, M.G.I., Navarro, I., Astiasarán, I., Ansorena, D., Cavero, R.Y., Calvo, M.I. (2011). Chemical composition, mineral content and antioxidant activity of Verbena officinalis L. LWT - Food Science and Technology, 44(4), 875-882.

https://doi.org/10.1016/j.Iwt.2010.11.035

32. Rybicka, I., Gliszczyńska-Świgło, A. (2017). Minerals in grain gluten-free products. The content of calcium, potassium, magnesium, sodium, copper, iron, manganese, and zinc. Journal of Food Composition and Analysis, 59, 61-67. https://doi.org/10.1016/j.jfca.2017.02.006

33. Shi, L., Arntfield, S.D., Nickerson, M. (2018). Changes in levels of phytic acid, lectins and oxalates during soaking and cooking of Canadian pulses. Food Research International, 107, 660-668. https://doi.org/10.1016/j.foodres.2018.02.056

34. Smýkal, P., Aubert, G., Burstin, J., Coyne, C.J., Ellis, N.T.H., Flavell, A.J., Ford, R., Hýbl, M., Macas, J., Neumann, P., McPhee, K.E., Redden, R.J., Rubiales, D., Weller, J.L., Warkentin, T.D. (2012). Pea (Pisum sativum L.) in the genomic era. Agronomy, $2,74-115$. https://doi.org/10.3390/agronomy2020074

35. Sotler, R., Poljšak, B., Dahmane, R., Jukić, T., Jukić, D.P., Rotim, C., Trebše, P., Starc, A. (2019). Prooxidant activities of antioxidants and their impact on health. Acta Clinica Croatica, 58(4), art. no. 726 . https://doi.org/10.20471/acc.2019.58.04.20

36. Sulaiman, S.F., Yusoff, N.A.M., Eldeen, I.M., Seow, E.M., Sajak, A.A.B., Ooi, K.L. (2011). Correlation between total phenolic and mineral contents with antioxidant activity of eight Malaysian bananas (Musa sp.). Journal of Food Composition and Analysis, 24(1), 1-10.

https://doi.org/10.1016/j.jfca.2010.04.005

37. Summo, C., Centomani, I., Paradiso, V.M., Caponio, F., Pasqualone, A. (2016). The effects of the type of cereal on the chemical and textural properties and on the consumer acceptance of precooked, legume-based burgers. LWT - Food Science and Technology, 65, 290-296.

https://doi.org/10.1016/j.lwt.2015.08.009

38. Summo, C., De Angelis, D., Ricciardi, L., Caponio, F., Lotti, C., Pavan, S., Pasqualone, A. (2019a). Data on the chemical composition, bioactive compounds, fatty acid composition, physicochemical and functional properties of a global chickpea collection. Data in Brief, 27, art. no. 104612. https://doi.org/10.1016/j.dib.2019.104612

39. Summo, C., De Angelis, D., Ricciardi, L., Caponio, F., Lotti, C., Pavan, S., Pasqualone, A. (2019b). Nutritional, physico-chemical and functional characterization of a global chickpea collection. Journal of Food Composition and Analysis, 84, art. no. 103306.

https://doi.org/10.1016/j.jfca.2019.103306

40. Summo, C., De Angelis, D., Rochette, I., Mouquet-Rivier, C., Pasqualone, A. (2019c). Influence of the preparation process on the chemical composition and nutritional value of canned purée of kabuli and Apulian black chickpeas. Heliyon, 5(3), art. no. e01361.

https://doi.org/10.1016/j.heliyon.2019.e01361

41. Tewari, R.K., Kumar, P., Sharma, N. (2006). Magnesium deficiency induced oxidative stress and antioxidant responses in mulberry plants. Scientia Horticulturae, 108, 7-14.

https://doi.org/10.1016/j.scienta.2005.12.006

42. Thaipong, K., Boonprakob, U., Crosby, K., Cisneros-Zevallos, L., Byrne, D.H. (2006). Comparison of ABTS, DPPH, FRAP, and ORAC assays for estimating antioxidant activity from guava fruit extracts. Journal of Food Composition and Analysis, 19(6-7), 669-675.

https://doi.org/10.1016/j.jfca.2006.01.003

43. Vandemark, G.J., Grusak, M.A., McGee, R.J. (2018). Mineral concentrations of chickpea and lentil cultivars and breeding lines grown in the US Pacific Northwest. The Crop Journal, 6(3), 253-262. https://doi.org/10.1016/j.cj.2017.12.003

44. Wang, N., Daun, J.K. (2004). Effect of variety and crude protein content on nutrients and certain antinutrients in field peas (Pisum sativum). Journal of the Science of Food and Agriculture, 84(9), 1021-1029.

https://doi.org/10.1002/jsfa.1742

45. Xu, Y., Burton, S., Kim, C., Sismour, E. (2016). Phenolic compounds, antioxidant, and antibacterial properties of pomace extracts from four Virginia grown grape varieties. Food Science and Nutrition, 4(1), 125-133.

https://doi.org/10.1002/fsn3.264

46. Yao, Y., Yang, X., Tian, J., Liu, C., Cheng, X., Ren, G. (2013). Antioxidant and antidiabetic activities of black mung bean (Vigna radiata L.). Journal of Agricultural and Food Chemistry, 61(34), 8104-8109. https://doi.org/10.1021/jf401812z

47. Zhang, B., Deng, Z., Tang, Y., Chen, P., Liu, R., Ramdath, D.D., Liu, Q., Hernandez, M., Tsao, R. (2014). Fatty acid, carotenoid and tocopherol compositions of 20 Canadian lentil cultivars and synergistic contribution to antioxidant activities. Food Chemistry, 161, 296-304.

https://doi.org/10.1016/j.foodchem.2014.04.014

48. Zia-Ul-Haq, M., Amarowicz, R., Ahmad, S., Riaz, M. (2013). Antioxidant potential of some pea (Pisum sativum L.) cultivars commonly consumed in Pakistan. OXID Community Edition, 36(4), 1046-1057. 